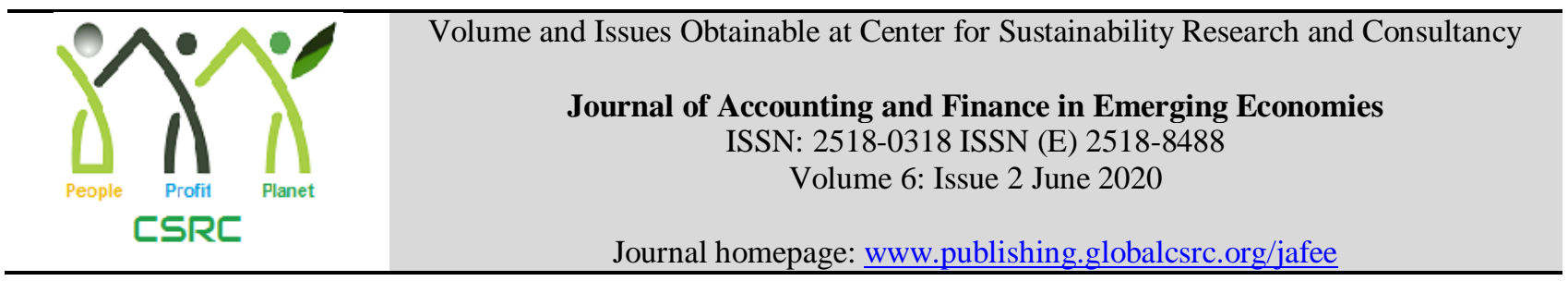

\title{
High Involvement Management Practices and Employees' OCBs in Banking Sector of Pakistan
}

\author{
${ }^{1}$ Muhammad Waseem, ${ }^{2}$ Sher Ali, ${ }^{3}$ Hazrat Bilal, ${ }^{4}$ Arshad Ali Khan
}
${ }^{1}$ Assistant Professor, Department of Management Sciences, Hazara University Mansehra Pakistan, mwaseem@hu.edu.pk
${ }^{2} \mathrm{PhD}$ Scholar in Management Sciences and Engineering, China Three Gorges University, College of Economics and Management, 443000 Yichang, China p.R, sherali9404@gmail.com
${ }^{3}$ Center for Management and Commerce, University of Swat, Swat Pakistan, hbilal@uswat.edu.pk
${ }^{4}$ Treasurer, University of Swat, Swat Pakistan, arshad.khan@uswat.edu.pk

\section{ARTICLE DETAILS}

\section{History}

Revised format: May 2020

Available Online: June 2020

\section{Keywords}

HIHRM, Involvement,

Organizational Citizenship

Behavior, Banking Sector

JEL Classification

$\mathrm{MO}, \mathrm{M} 14$

\section{ABSTRACT}

This study was designed to evaluate the impact of high involvement HRM practices (HIHRP) on employees' organizational citizenship behaviors (OCBs) in the context of banking sector of Pakistan. OCBs is considered as an important construct to evaluate the contextual performance of employees. In case of banking sector professionals, it is a highly desired behavior and top management has a greater interest in evaluating contextual performance in addition to the task performance of employees. This study differentiates itself from previous studies by focusing on HIHRP rather than traditional HRM practices. The data was collected from 396 officers working in top six private sector commercial banks of Pakistan. A structured questionnaire was used to collect the data and all responses were recorded on Likert scale. The data was analyzed through correlation and regression analysis and demographic characteristics of the employees were also presented through descriptive statistical techniques. The results show that different types of HIHRP positively influences employees' OCBs. This study has both theoretical and managerial contributions by empirically examining the relationship between high involvement HRM practices and OCBs in the context of banking sector of Pakistan. The results of this study will help the researchers to better understand the relationship between HRM practices employees' positive behavioral outcomes like OCBs. In addition, it will also guide the decision makers in adjusting HRM practices to achieve desired behaviors.

\section{OPEN ACCESS}

Corresponding author's email address: hbilal@uswat.edu.pk

Recommended citation: Waseem, M., Ali, S., Bilal, H., and Khan, A. A. (2020). High Involvement Management Practices and Employees' OCBs in Banking Sector of Pakistan. Journal of Accounting and Finance in Emerging Economies, 6(2), 529-538 


\section{Background}

Although importance of HRM practices in influencing employees behavioral outcomes is widely acknowledged in the literature, however, from the past few years, the HRM literature highlighted that organizations have to focus on HRM practices that are highly connected with the needs of organization. In today's dynamic and complex business environment the desired results cannot be achieved without strategically aligned HRM practices (Jiang, Lepak, Hu, \& Baer, 2012).

This is apparent in a recent literature that employees' behaviors are greatly influenced by a set of HRM practices (Ahmad and Schroeder, 2003) and that different practices may affect differently (Scarbrough, 2000). Thus, HRM practices are bundled to influence certain employees' behaviors (Takeuchi \& Takeuchi, 2013). Therefore, it is important to investigate and identify a set of suitable HRM practices and determining their role in influencing employees' behaviors. Appelbaum et al., (2000) argued that high performing firms use the five diverse and empathetic high involvement HRM practices to promote positive employees and organizational outcomes. Paré, \& Tremblay (2007) also highlighted different types of HIHRP in organizations.

The main purpose of this study is to understand the concept of HIHRP and evaluating their impact on employees' OCBs. HIHRP are selected because of their potential to improve employees task performance as well as the contextual performance of employees (Huselid, 1995; Batt, 2002). High-involvement HRM practices also promote relationship-based development strategies that help firms to attract and retain the talented employees (McAfee et al., 2002). McMahan, Bell, \& Virick (1998) suggested that high-involvement model presented by Lawler (1986) is considered as an important milestone in the development of existing strategic HRM literature.

\section{Literature}

Ostroff and Bowen, (2000) argued that Human Resource (HR) practices are considered as an important source of signaling top management' priorities and social exchange relationships. HR practices elaborate in HPWS promotes a sympathetic atmosphere in which employees are more involved in decisions effecting their work life (Ostroff and Bowen, 2000). Jiang et al., (2012) suggested that HIHRP leads to better performance outcomes.

Appelbaum et al., (2000) and Paré, \& Tremblay (2007) suggested five diverse high involvement HRM practices which include: employee empowerment, skills development, knowledge sharing, motivation, and a fair organizational rewards system. It was highlighted that that such type of employees oriented, and supportive HRM practices positively influence the helping behaviors like OCBs. The empathetic nature of HIHRP develops positive feelings in individuals and employees tend to respond positively through helping behaviors (Eisenberger, Fasalo, \& DavisLaMastro, 1990.

In recent past, a number of researchers studied the effects of HIHRP (Jiang, 2016). Ang et al., (2013) argued that employees view the HIHRP positively as compare to the traditional HR practices. Boxall and Macky (2007) suggested that HIHRP had a great effect on employees' attitudinal and behavioral outcomes. Demirbag et al., (2014) referred HIHRM as the practices that focus on investments in human resource of an organization, employee empowerment, effective HRD practices, fair compensation and motivation. The theoretical base of HIHRP can be traced back to human capital theory where KSAs of workforce are increased through HR functions like HR staffing and HRD (Jiang et al., 2012).

Employees creativity and proactive behaviors play their role in improving organizational performance, therefore, HRM practices needs to be directed towards them (Shin, Jeong, \& Bae, 2018). Firms can improve employees' trust and satisfaction through employees' involvement in organizational level decisions (Korff et al., 2017). The social exchange theory (Blau, 1964) and organizational support theory (Eisenberger et al., 1986) suggests that firms can signal its care for the wellbeing and development of employees through HIHRP. Lawler (2008) found that HIHRP positively influences employees work related behavioral outcomes.

Banking sector is more completive in nature and they always try to improve customer services through better customer services and introducing new products and services. HIHRP can play an important role in developing 
employees' positive attitudes and behaviors in banking sector by improving employees' perception about their organization which in turn influences employees' performance. Appelbaum et al. (2000) argued that high performing firms use five diverse and empathetic HRM practices that have a great potential to affect employees' outcomes. The main purpose of this research study is to evaluate the effect of HIHRP on employees' OCBs in the context of banking sector of Pakistan.

\subsection{High Involvement HRM Practices and OCBs}

Paré, \& Tremblay (2007) identified that high performing firms use five HIHRP to improve employees' performance. OCBs refers to employees helping behavior in which employees are willing to perform extra role performance along with their task performance to contribute in the success of their organization (Organ, 1990). Morrisson (1996) argued that HRM practices contribute in promoting organizational citizenship behaviors among employees because HRM practices are important source of developing and defining employer-employee relationship. The HIHRP signals employees that their organization cares for them and working for the wellbeing of workforce. Such type of HRM practices develops employees trust in their organization and they also feel obligatory to show the helping behaviors (Eisenberger et al., 1986).

\subsection{Employee's Empowerment and OCBs}

Employees empowerment is an important concept and is considered as an important tool in developing ownership in employees. It provides more autonomy and flexibility to the employees in exercise of their duties and responsibilities. Employees autonomy and control over their tasks give them the feelings of involvement and ownership (Eby et al., 1999). Accordingly, the following hypothesis was developed:

Hypothesis 1: Employees empowerment positively influences employees OCBs.

\subsection{Employees' Development Oriented HRM Practices and OCBs}

High-performing firms also use development oriented HRM practices i.e. job rotation, job enrichment, mentoring, and training. Such type of development oriented HRM practices not only help in increasing the performance of existing employees but also develop positive perception in employees that their employer is investing in them and they reciprocate the same with helping behaviors like OCBs (Eisenberger et al., 1986, Morrison, 1996). Thus, the following hypothesis was developed:

Hypothesis 2: Employees development oriented HIHRP leads to employees OCBs.

\subsection{Knowledge Sharing HRM Practices and OCBs}

The third important high involvement HRM practice is known as knowledge sharing. Several authors highlighted the importance of knowledge and information sharing practices. It is suggested that knowledge sharing help firms to develop a learning environment in which employees freely share their experiences and information with others which help in realization of organizational goals (Rodwell, Kienzle, \& Shadur, 1998). It also helps in developing shared values in employees, building mutual trust, and developing positive feelings in employees. Hence, the following hypothesis was developed:

Hypothesis 3: Knowledge sharing HIHRP improves employees OCBs.

\subsection{Employees' Motivation Enhancing HRM Practices and OCBs}

Employees' motivation is also suggested as an important high involvement HRM practice. In HRM literature, motivation has been widely acknowledged as a fundamental driver of human behavior. Both monitory and nonmonitory rewards were considered as a motivating factor, however, for highly skilled professionals, the recognition of their performance and feelings of ownership in organization are important source of motivation (Minbaeva, 2008). A number of researchers suggested that high-performance organizations use different methods to regularly recognize the valuable contributions of the employees (e.g., Bradler, Dur, Neckermann, \& Non, 2016). Consequently, it can be concluded that organization's care and recognition of employees' effort will yield positive and helping behaviors in employees. On the basis of this, the following hypothesis was developed: 
Hypothesis 4: Employees' motivation enhancing HRM practices improves employees OCBs.

\subsection{Fair Reward System and OCBs}

Similarly, the maintenance of a fair rewards system in organization as acknowledged as another important feature of high performing organizations. It is suggested that perceived fairness of organizational rewards signals employees that their organization cares for them and treat them fairly in distribution of benefits (Eisenberger et al., 1986; Lawler, 1986). Accordingly, we also have developed the following hypothesis:

Hypothesis 5: Fair Rewards management practices have a positive impact on employees OCBs.

This study is an important endeavor, as it is an effort to provide empirical support on the relationship between high involvement HR Practices and employees' OCBs in the context of Pakistan. The focus of previous studies was mainly on evaluating the impact of traditional HR practices while this study highlighted the importance of high performance work system through high involvement HRM practices. The following theoretical framework shown in Figure 1 has been developed on the basis of review of literature:

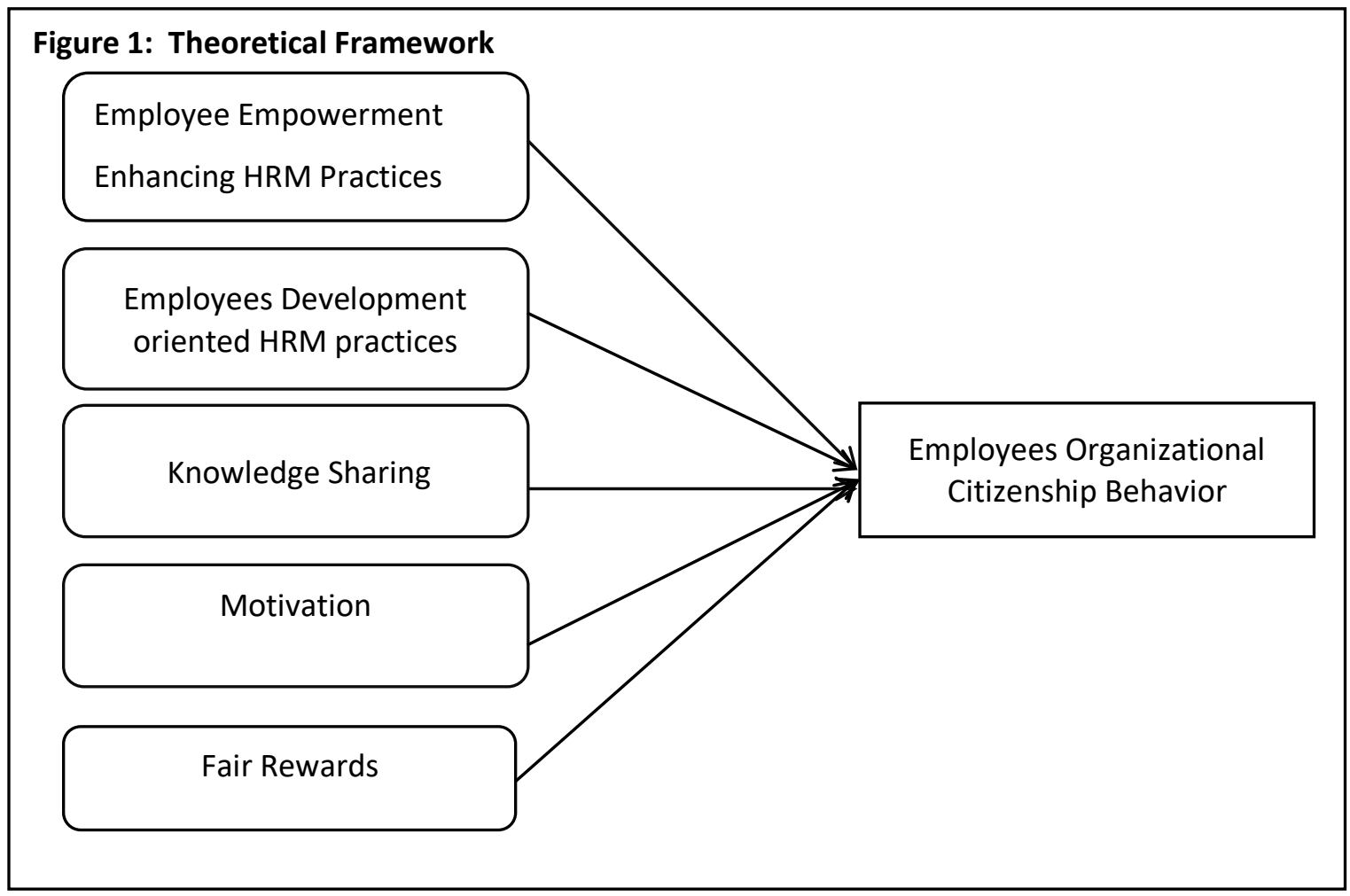

\section{Methodology}

This study is quantitative in nature and survey approach was used. The data was collected from the officers working in banking sector. The banking sector is one of the largest employers in the service sector of Pakistan and is significantly contributing in the economic development of Pakistan. A total of 410 officers were selected as sample using convenience sampling technique. The officers selected were performing their duties as branch managers or operational managers in different branches of banks in Pakistan.

\subsection{Data Collection}

The survey approach used for data collection and the confidentiality of individual responses was ensured to the respondents through cover letter and prior consent was also obtained. The process of data collection took three months. Out of 410 questionnaires a total of 396 questionnaires were found complete in all respects, hence used for data analysis.

\subsection{Measures}


The research instrument of the study consists of two sections. In first section, the data was obtained with respect to gender, education level and experience of participants. The second section consist of the measures for each variable. All responses were recorded on 7 point Likert scale ranging from 1 'strongly disagree' to 7 'strongly agree'.

The standardized measures were used for collecting data, as standardized questionnaire, overcomes the problems of validity and reliability of the instrument. The variable "High involvement human resource practices" was measured through 5 sub dimensions identified in literature (e.g Lawler, Mohrman, \& Ledford, 1992; Paré, \& Tremblay, 2007; Tremblay, Rondeau, and Lemelin, 1998). Each dimension was measured through relevant items by the help of available literature. Employees' empowerment was measured using a three-item scale, employees development practices were measured using a six-item scale. Knowledge-sharing practices were measured using a nine-item scale. For employees' motivation enhancing HRM practices, a six-item scale was used. Fair rewards system was measured using a five-item scale. Similarly, variable OCBs was measured through 5 items scale adopted from (Podsakoff, Ahearne \& MacKenzie, 1997). The details of measures are given in Table 1 along with Cronbach alpha values. The Cronbach alpha value of all the variables were found above the threshold value of 0.7 which indicates the reliability of the measures used in this study.

Table 1: Reliability Analysis of Research Instrument

\begin{tabular}{lcc}
\hline Variables & No of items & Cronbach alpha \\
\hline High Involvement HRM Practices & & \\
Employees' empowerment HR practices & 03 & 0.72 \\
Employees development oriented HR practices & 06 & 0.90 \\
Knowledge sharing HR practices & 09 & 0.89 \\
Motivation Enhancing HRM practices & 06 & 0.87 \\
Fair Reward System & 05 & 0.90 \\
Organizational citizenship behavior & 05 & 0.88 \\
\hline
\end{tabular}

\section{Data Analysis}

Both descriptive and inferential statistical tools were applied in data analysis. Respondent profile was described through frequency distribution. Hypotheses were tested through correlation and regression techniques. The reliability of scales was tested by using Cronbach alpha $(\alpha)$. The SPSS version 21 is used in data analysis.

\subsection{Respondent's Profile}

The following section presents the data regarding different demographic profile of the participants shown in the Table 2:

Table 2: Demographics Profile

\begin{tabular}{|c|c|c|}
\hline Descriptions & Percentage & Frequency \\
\hline \multicolumn{3}{|l|}{ Gender } \\
\hline Male & 73.7 & 292 \\
\hline Female & 26.3 & 104 \\
\hline \multicolumn{3}{|l|}{ Educational Qualification } \\
\hline M.Phil & 16.2 & 64 \\
\hline Masters & 71.7 & 284 \\
\hline Under Graduates & 12.1 & 48 \\
\hline \multicolumn{3}{|l|}{ Work Experience } \\
\hline$>12$ years & 45.2 & \\
\hline $10-12$ years & 31.8 & 179 \\
\hline 7-9 years & 2.4 & 126 \\
\hline 4-6 years & 6.1 & 49 \\
\hline$<3$ years & 4.5 & 24 \\
\hline & & 18 \\
\hline
\end{tabular}


In the above Table 2 , it is stated that a majority of the respondents i.e. about 73.7 percent were the male respondents while ratio of female were only 26.3 percent. Similarly, majority of the respondents are well qualified and more than $87 \%$ of the respondents were having 16 years or a higher qualification. With reference to the experience of respondents, the majority of them in the first two categories with experience of more than 10 years. It shows that majority of the respondents were experienced mid-career banking sector professionals.

\subsection{Hypotheses Testing}

Hypotheses were tested through correlation and regression analysis. Correlation analysis was used to check the degree of association and the direction of relationships among the variables of the study. After that the impact of each dimension of high involvement HRM practices was evaluated through regression analysis. At the end all items of high involvement HRM practices were combined and regressed on OCBs to check the overall effect of those practices on OCBs.

\subsection{Correlation Analysis}

Correlation analysis is used to evaluate the degree of association between the variables of the study. The details are presented in Table 3. It is found that all dimensions of High involvement HRM practices have a significant and positive correlation with OCBs. The results show that all the dimensions of high involvement HRM practices are the important predictors of employees OCBs. The managers can improve employees helping behaviors like OCBs by using these practices in their organizations.

Table 3: Correlation Matrix

\begin{tabular}{|c|c|c|c|c|c|c|}
\hline & Empowerment & $\begin{array}{c}\text { Knowledge } \\
\text { sharing }\end{array}$ & Motivation & Fair rewards & HRD & OCBs \\
\hline Empowerment & 1 & & & & & \\
\hline Knowledge sharing & $.563^{* *}$ & 1 & & & & \\
\hline Motivation & $.553^{* *}$ & $.782^{* *}$ & 1 & & & \\
\hline Fair rewards & $.557^{* *}$ & $.765^{* *}$ & $.851^{* *}$ & 1 & & \\
\hline HRD & $.665^{* *}$ & $.790^{* *}$ & $.658^{* *}$ & $.660^{* *}$ & 1 & \\
\hline OCBs & $.553^{* *}$ & $.791^{* *}$ & $.822^{* *}$ & $.891^{* *}$ & $.675^{* *}$ & 1 \\
\hline Significant & .000 & .000 & .000 & .000 & .000 & \\
\hline $\mathrm{N}$ & 396 & 396 & 396 & 396 & 396 & 396 \\
\hline
\end{tabular}

\subsection{Regression Analysis}

Regression analysis was used to evaluate the impact of different HRM practices on employees OCBs. The regression analysis is a useful statistical tool of social sciences research when the researchers are interested in evaluating the effect of an independent variable on certain dependent variable. In this study, in first step the individual impact of each dimension of HIHRP were evaluated.

\subsection{Employees Empowerment and OCBs}

In first hypothesis of the study it was assumed that the high involvement HRM practices which empower employees in the performance of their tasks have a positive effect on employees OCBs.

Table 4: Model Summary (Model 1)

\begin{tabular}{|c|c|c|c|c|}
\hline Model 1 & $\mathrm{R}$ & R Square & Adjusted R Square & Std. Error of the Estimate \\
\hline & $.553^{\mathrm{a}}$ & .305 & .304 & .837 \\
\hline
\end{tabular}

a. Dependent Variable: OCBS 


\section{Table 5: Coefficients}

\begin{tabular}{|c|c|c|c|c|c|}
\hline \multirow[t]{2}{*}{ Model 1} & \multicolumn{2}{|c|}{$\begin{array}{c}\text { Unstandardized } \\
\text { Coefficients }\end{array}$} & \multicolumn{2}{|c|}{ Standardized Coefficients } & \multirow{2}{*}{$\begin{array}{c}\text { Sig. } \\
\text { B }\end{array}$} \\
\hline & $\mathrm{B}$ & $\begin{array}{l}\text { Std. } \\
\text { Error }\end{array}$ & Beta & $\mathrm{t}$ & \\
\hline (Constant) & 2.407 & .236 & & 10.201 & .000 \\
\hline Empowerment & .552 & .042 & .553 & 13.164 & .000 \\
\hline
\end{tabular}

a. Dependent Variable: OCBs

The results $\left(\mathrm{R}^{2} .305, \beta .553 \& \mathrm{p}\right.$ value 0.000$)$ presented in Table 4 and Table 5 indicate that the HRM practices that fosters employee empowerment have a positive impact on employees OCBs. Hence the hypothesis 1 of the study is accepted.

\subsection{Employees Development and OCBs}

In hypothesis 2 of this study it was proposed that high involvement HRM practices that focuses on developing employees' competencies have a significant positive impact on OCBs.

Table 6: Model Summary (Model 2)

\begin{tabular}{lllll}
\hline Model 2 & $\mathrm{R}$ & R Square & $\begin{array}{l}\text { Adjusted R } \\
\text { Square }\end{array}$ & $\begin{array}{l}\text { Std. Error of the } \\
\text { Estimate }\end{array}$ \\
\hline $.675^{\text {a }}$ & .456 & .455 & .741 \\
\hline
\end{tabular}

a. Dependent Variable: OCBs

Table 7: Coefficients

\begin{tabular}{|c|c|c|c|c|c|}
\hline \multirow[t]{2}{*}{ Model 2} & \multicolumn{2}{|c|}{$\begin{array}{l}\text { Unstandardized } \\
\text { Coefficients }\end{array}$} & \multicolumn{2}{|l|}{$\begin{array}{l}\text { Standardized } \\
\text { Coefficients }\end{array}$} & \multirow{2}{*}{$\begin{array}{c}\text { Sig. } \\
\text { B }\end{array}$} \\
\hline & $\mathrm{B}$ & $\begin{array}{c}\text { Std. } \\
\text { Error }\end{array}$ & Beta & $\mathrm{t}$ & \\
\hline (Constant) & 1.783 & .206 & & 8.664 & .000 \\
\hline $\begin{array}{l}\text { Employee } \\
\text { Development }\end{array}$ & .672 & .037 & .675 & 18.182 & .000 \\
\hline
\end{tabular}

a. Dependent Variable: OCBs

The results $\left(\mathrm{R}^{2} .456, \beta .675 \& \mathrm{p}\right.$ value 0.000$)$ presented in Table 6 and Table 7 indicate that the HRM practices that focuses on developing employees' competencies have a positive impact on employees OCBs. Hence the hypothesis 2 of the study is accepted.

\subsection{Knowledge Sharing HRM Practices and OCBs}

In hypothesis 3 of the existing study, it was proposed that high involvement HRM practices which facilitates information/knowledge sharing have a significant positive impact on OCBs.

Table 8: Model Summary (Model 3)

\begin{tabular}{lllll}
\hline Model 3 & R & R Square & Adjusted R Square & Std. Error of the Estimate \\
\hline & $.791^{\text {a }}$ & .626 & .625 & .615 \\
\hline
\end{tabular}

a. Dependent Variable: OCBs

Table 9: Coefficients

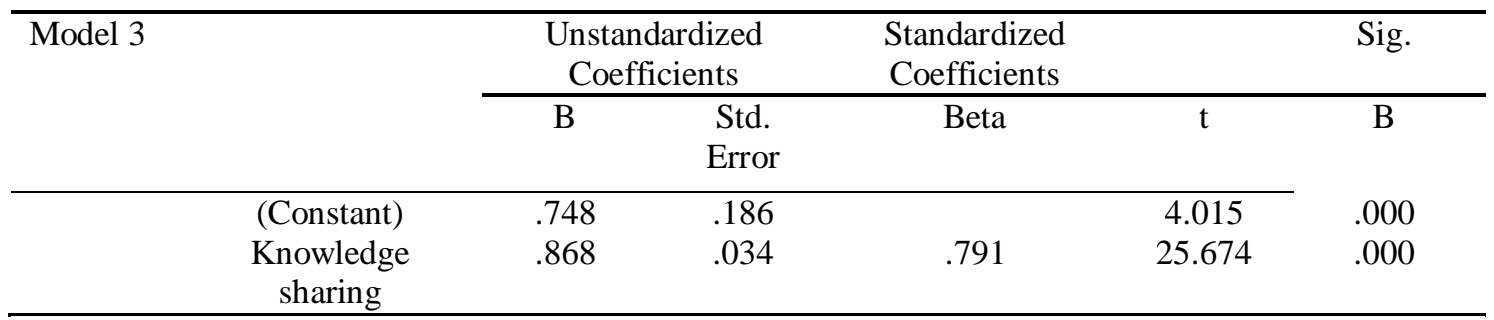

a. Dependent Variable: OCBs 
From the results $\left(\mathrm{R}^{2} .626, \beta .791 \& \mathrm{p}\right.$ value 0.000$)$ presented in Table 8 and Table 9 it is concluded that the HRM practices that focuses facilitates the sharing of information among employees have a positive impact on employees OCBs. Therefore, the hypothesis 3 of the study is accepted.

\subsection{Motivation Enhancing HRM practices and OCBs}

In hypothesis 4 of this study, it was proposed that high involvement HRM practices which enhances employees' motivation helps to improve employees OCBs.

Table 10: Model Summary (Model 4)

\begin{tabular}{llll}
\hline Model 4 & R & R Square & Adjusted R Square \\
\hline $.822^{\mathrm{a}}$ & .676 & .675 & Std. Error of the Estimate \\
\hline
\end{tabular}

a. Dependent Variable: OCBs

Table 11: Coefficients

\begin{tabular}{|c|c|c|c|c|c|}
\hline \multirow[t]{2}{*}{ Model 4} & \multicolumn{2}{|c|}{$\begin{array}{c}\text { Unstandardized } \\
\text { Coefficients }\end{array}$} & \multirow{2}{*}{$\begin{array}{c}\begin{array}{c}\text { Standardized } \\
\text { Coefficients }\end{array} \\
\text { Beta }\end{array}$} & \multirow[t]{2}{*}{$\mathrm{t}$} & \multirow{2}{*}{$\begin{array}{c}\text { Sig. } \\
\text { B }\end{array}$} \\
\hline & $\mathrm{B}$ & $\begin{array}{l}\text { Std. } \\
\text { Error }\end{array}$ & & & \\
\hline (Constant) & .778 & .166 & & 4.689 & .000 \\
\hline Motivation & .860 & .030 & .822 & 28.654 & .000 \\
\hline
\end{tabular}

a. Dependent Variable: OCBs

From the results $\left(\mathrm{R}^{2} .676, \beta .822 \& \mathrm{p}\right.$ value 0.000$)$ presented in Table 10 and Table 11 it is proved that the high involvement HRM practices that enhances level of employees' motivation have a positive impact on employees OCBs. Therefore, the hypothesis 4 of the study is accepted.

\subsection{Fair Rewards Management and OCBs}

The hypothesis 5 of this study states that maintenance a fair reward system positively influences employees OCBs.

Table 12: Model Summary (Model 5)

\begin{tabular}{llll}
\hline Model 5 & R & R Square & Adjusted R Square \\
\hline $.891^{\mathrm{a}}$ & .793 & Std. Error of the Estimate \\
\hline
\end{tabular}

a. Dependent Variable: OCBs

Table 13: Coefficients

\begin{tabular}{|c|c|c|c|c|c|}
\hline \multirow[t]{2}{*}{ Model 5} & \multicolumn{2}{|c|}{$\begin{array}{l}\text { Unstandardized } \\
\text { Coefficients }\end{array}$} & \multirow{2}{*}{$\begin{array}{l}\text { Standardized } \\
\text { Coefficients } \\
\text { Beta }\end{array}$} & & Sig. \\
\hline & B & $\begin{array}{l}\text { Std. } \\
\text { Error }\end{array}$ & & $\mathrm{t}$ & B \\
\hline (Constant) & .795 & .122 & & 6.496 & .000 \\
\hline Fair rewards & .862 & .022 & .891 & 38.863 & .000 \\
\hline
\end{tabular}

a. Dependent Variable: OCBs

From the results $\left(\mathrm{R}^{2} .793, \beta .891 \& \mathrm{p}\right.$ value 0.000$)$ presented in Table 12 and Table 13 it is proved that the high involvement HRM practices promotes fairness in reward management in their organization which leads to develop employees OCBs. Therefore, on the basis of these results, the hypothesis 5 of the study is also accepted.

\section{Discussion and Implications}

The current findings provided an empirical base regarding the use of high involvement HRM practices in developing positive employees' behaviors. It was found that HIHRP are important source of developing helping behaviors like OCBs in organization because HIHRP are more empathetic, supportive, and flexible in nature. The findings of this study further confirmed the notion that today's competitive environment needs high level of employees' involvement in decision making (Rangus \& Slavec, 2017). The findings also provided strong empirical support for the theoretical distribution of five high involvement HRM practices in the context of Pakistan, where most of the research studies are 
still focused on use of traditional HRM practices. These results further confirmed the utility of these practices in developing positive and helping behaviors as suggested by Paré, \& Tremblay (2007). HIHRP can be an important source of conveying organizations care for the wellbeing of its employees which in turn encourages employee to show positive behaviors towards their organization. For example, employees' empowerment develops employees trust on organization (Appelbaum et al., 2000). Similarly, if a firm provides skills development opportunities to its employees and recognize their efforts it will improve OCBs. HIHRP encourages the employees to freely share their knowledge and experience with others and better utilize their competencies (Allen et al., 2003).

\section{Conclusions}

This study was designed to find out the empirical support for a set of HIHRP which were identified in literature. Specifically, in the context of banking sector of Pakistan, a strong empirical support was found. The top managers can use HIHRP to improve their competitiveness by empowering employees, focusing on developing their KSAs, by providing opportunities to learn and share, recognizing their efforts through a fair system of intrinsic and extrinsic rewards. The study highlighted the importance of adopting HRM practices that signals organizations care and support for employees' wellbeing. Such type of employees oriented HRM practices develops the feelings of importance for their organization and they also tend to reciprocate with helping behaviors like OCBs.

\section{References}

Ahmad, S., \& Schroeder, R. G. (2003). The impact of human resource management practices on operational performance: recognizing country and industry differences. Journal of operations Management, 21(1), 19-43.

Ang, S. H., Bartram, T., McNeil, N., Leggat, S. G., \& Stanton, P. (2013). The effects of high-performance work systems on hospital employees' work attitudes and intention to leave: a multi-level and occupational group analysis. The International Journal of Human Resource Management, 24(16), 3086-3114.

Allen, James R. "Concepts, competencies, and interpretive communities." Transactional Analysis Journal 33, no. 2 (2003): 126-147.

Appelbaum, E., Bailey, T., Berg, P., \& Kalleberg, A. L. (2000). Manufacturing advantage: Why high-performance work systems pay off. Ithaca, NY: Cornell University Press.

Batt, R. (2002). Managing customer services: Human resource practices, quit rates, and sales growth. Academy of management Journal, 45(3), 587-597.

Bradler, C., Dur, R., Neckermann, S., \& Non, A. (2016). Employee recognition and performance: A field experiment. Management Science, 62(11), 3085-3099.

Boxall, P., \& Macky, K. (2007). High-performance work systems and organisational performance: Bridging theory and practice. Asia Pacific Journal of Human Resources, 45(3), 261-270.

Blau, P. (1964). Exchange and power in social life. Wiley, NY.

Demirbag, M., Collings, D. G., Tatoglu, E., Mellahi, K., \& Wood, G. (2014). High-performance work systems and organizational performance in emerging economies: Evidence from MNEs in Turkey. Management

International Review, 54(3), 325-359.

Eisenberger, R., Huntington, R., Hutchison, S., \& Sowa, D. (1986). Perceived organizational support. Journal of Applied psychology, 71(3), 500.

Eisenberger, R., Fasolo, P., \& Davis-LaMastro, V. (1990). Perceived organizational support and employee diligence, commitment, and innovation. Journal of applied psychology, 75(1), 51.

Eby, L. T., Freeman, D. M., Rush, M. C., \& Lance, C. E. (1999). Motivational bases of affective organizational commitment: A partial test of an integrative theoretical model. Journal of occupational and organizational psychology, 72(4), 463-483.

Huselid, M. A. (1995). The impact of human resource management practices on turnover, productivity, and corporate financial performance. Academy of Management Journal, 38, 635-662

Jiang, K., Lepak, D. P., Hu, J., \& Baer, J. C. (2012). How does human resource management influence organizational outcomes? A meta-analytic investigation of mediating mechanisms. Academy of management Journal, 55(6), 1264-1294.

Jiang, K. (2016). Strategic human resource management and organizational commitment. In Handbook of employee commitment. Edward Elgar Publishing.

Korff, J., Biemann, T., \& Voelpel, S. C. (2017). Human resource management systems and work attitudes: The mediating role of future time perspective. Journal of Organizational Behavior, 38(1), 45-67. 
Lawler III, E. E. (1986). High-Involvement Management. Participative Strategies for Improving Organizational Performance. Jossey-Bass Inc., Publishers, 350 Sansome Street, San Francisco, CA 94104.

Lawler, J. J., Chen, S. J., Wu, P. C., Bae, J., \& Bai, B. (2008). High performance work system practices in foreign subsidiaries of American multinationals: A multi-country study.

Lawler, E. E., Mohrman, S. A., \& Ledford, G. E. (1992). Employee involvement and total quality management: Practices and results in Fortune 1000 companies. Jossey-Bass Inc Pub.

McAfee, R. B., Glassman, M., \& Honeycutt Jr, E. D. (2002). The effects of culture and human resource management policies on supply chain management strategy. Journal of Business logistics, 23(1), 1-18.

McMahan, G. C., Bell, M. P., \& Virick, M. (1998). Strategic human resource management: Employee involvement, diversity, and international issues. Human Resource Management Review, 8(3), 193-214.

Morrison, E. W. (1996). Organizational citizenship behavior as a critical link between HRM practices and service quality. Human resource management, 35(4), 493-512.

Minbaeva, D. B. (2008). HRM practices affecting extrinsic and intrinsic motivation of knowledge receivers and their effect on intra-MNC knowledge transfer. International business review, 17(6), 703-713.

Ostroff, C., \& Bowen, D. E. (2000). Moving HR to a higher level: HR practices and organizational effectiveness.

Organ, D. W. (1990). The motivational basis of organizational citizenship behavior. Research in organizational behavior, 12(1), 43-72.

Paré, G., \& Tremblay, M. (2007). The influence of high-involvement human resources practices, procedural justice, organizational commitment, and citizenship behaviors on information technology professionals' turnover intentions. Group \& Organization Management, 32(3), 326-357.

Podsakoff, P. M., Ahearne, M., \& MacKenzie, S. B. (1997). Organizational citizenship behavior and the quantity and quality of work group performance. Journal of applied psychology, 82(2), 262.

Rangus, K., \& Slavec, A. (2017). The interplay of decentralization, employee involvement and absorptive capacity on firms' innovation and business performance. Technological Forecasting and Social Change, 120, 195-203.

Rodwell, J. J., Kienzle, R., \& Shadur, M. A. (1998). The relationship among work-related perceptions, employee attitudes, and employee performance: The integral role of communications. Human Resource Management: Published in Cooperation with the School of Business Administration, The University of Michigan and in alliance with the Society of Human Resources Management, 37(3-4), 277-293.

Shin, S. J., Jeong, I., \& Bae, J. (2018). Do high-involvement HRM practices matter for worker creativity? A crosslevel approach. The International Journal of Human Resource Management, 29(2), 260-285.

Scarbrough, H., \& Carter, C. (2000). Investigating knowledge management. London: Chartered Institute of Personnel and Development.

Saridakis, G., Lai, Y., \& Cooper, C. L. (2017). Exploring the relationship between HRM and firm performance: A meta-analysis of longitudinal studies. Human resource management review, 27(1), 87-96.

Takeuchi, N., \& Takeuchi, T. (2013). Committed to the organization or the job? Effects of perceived HRM practices on employees' behavioral outcomes in the Japanese healthcare industry. The International Journal of Human Resource Management, 24(11), 2089-2106.

Tremblay, M., Rondeau, A., \& Lemelin, M. (1998). Do innovative HR practices influence blue-collar workers' mobilization. In Proceedings of Meetings of Association Internationale de Psychologie de Langue

Franjaise (pp. 97-110). 